\title{
New species of Lopesia (Diptera, Cecidomyiidae) associated with Eichhornia azurea (Pontederiaceae) from Brazil
}

\author{
Maria V. Urso-Guimarães ${ }^{1}$, Marlon Peláez-Rodríguez² \& Susana Trivinho-Strixino ${ }^{3}$
}

\footnotetext{
1. Laboratório de Sistemática de Diptera, Departamento de Biologia, CCHB, Universidade Federal de São Carlos, Rod. João Leme dos Santos (SP-264), Km 110, 18052-780 Sorocaba, São Paulo, Brazil. (mvirginiaurso@gmail.com, virginia@ufscar.br)

2. Programa de Biología, Facultad de Ciencias Básicas, Universidad de la Amazonia, Av. Circunvalar, Barrio El Porvenir, Florencia (Caquetá), Colombia.

3. Departamento de Hidrobiologia, CCBS, Universidade Federal de São Carlos, Rod. Washington Luís (SP-310), Km 235, 13565-905 São Carlos, São Paulo, Brazil.
}

\begin{abstract}
A new species of gall midge, Lopesia eichhorniae sp. nov. (Cecidomyiidae, Diptera), associated with rhizomes of Eichhornia azurea (Sw.) Kunth (Pontederiaceae) is described. This is the first record of Lopesia galls in this species of macrophyte, quite common in natural and artificial lakes in Southeast Brazil. Illustrations of the adults (male and female), pupa, larva, and gall of the new species are presented.
\end{abstract}

KEYWORDS. Aquatic macrophyte, gall maker, rhizome galls, São Paulo, Neotropical.

RESUMO. Nova espécie de Lopesia (Cecidomyiidae, Diptera) associada a Eichhornia azurea (Pontederiaceae) do Brasil. Uma espécie nova de cecidomiídeo galhador, Lopesia eichhorniae sp. nov. (Cecidomyiidae, Diptera), associada a rizomas de Eichhornia azurea (Sw.) Kunth (Pontederiaceae) está sendo descrita neste trabalho. Esse é o primeiro registro de galhas de Lopesia nessa espécie de macrófita, muito comum em lagos naturais e artificiais na região Sudeste do Brasil. Ilustrações de adultos e imaturos da espécie nova e de suas galhas são apresentadas.

PALAVRAS-CHAVE. Galha em rizomas, galhador, macrófita aquática, São Paulo, Neotropical.

Eichhornia azurea (Sw.) Kunth (Pontederiaceae) is a permanent floating species, perennial, rhizomatous, known popularly as water hyacinth or camalote (Ротт \& Ротт, 2000). During all or part of their life cycles, a significant number of terrestrial and aquatic insects use this macrophyte as habitats for reproduction, for protection against predators, and as food resources (TRIVINHO-STRIXINO et al., 2000). The species is distributed in natural and artificial reservoirs from South of the United States to Argentina, and in all regions and ecosystems of Brazil (AMARAL, 2014).

Lopesiini is a tribe of 30 species in eight genera; all gall makers, and the majority with Neotropical distribution (GAGNÉ \& JASCHHOF, 2014). Lopesia Rübsaamen, 1908 has 18 species distributed in Brazil (RÜBSAamen, 1908; MaIA 2001, 2004; MaiA et al., 2002, 2010; MADEIRA et al., 2003; NARAhara et al., 2004; Fernandes, et al., 2010; RodRigues \& MAIA, 2010), and other five species known from Nearctic, Afrotropical, and Australasian regions (TAVARES, 1908; Gagné \& Marohasy, 1993; Gagné \& Hibbard, 1996; Kolesik \& PeAcock, 1999).

The galls induced by Lopesia species has various shapes, since leaf hairy spherical until swollen stem. They occur chiefly on species of Fabaceae, Clusiaceae, and Burseraceae families, also inducing galls in few species of Nyctaginaceae, Melastomataceae, Erythroxylaceae, Chrysobalanaceae, Sapotaceae, Euphorbiaceae, Rosaceae, and Myrtaceae. This is the first report of Lopesia galls in Pontederiaceae and in submersible rhizomes of Eichhornia azurea. The gall was already referred in PeLÁez-RodRíGuez et al. (2003) without formal description of the gall maker. In this paper, illustrations of the new species and from the galls are presented, as well as comments about its systematic position in genus.

\section{MATERIAL AND METHODS}

The sampled galls were collected in the Diogo Lake, localized in Jataí Ecological Station, Municipality of Luiz Antônio, northeast state of São Paulo, and Southeast region of Brazil. After the collection, the galls were transferred to individual plastic bags, for rearing the adults. Some of the galls were dissected under stereomicroscope to obtain immatures. All material was conserved in $70 \%$ alcohol. Some individuals were mounted following the technique and morphological terminology of GAGNÉ (1994). The material was illustrated and photographed under optic microscope and stereomicroscope. Other specimens were placed on scanning electron microscope stubs to scanning electron micrographs. The micrographs were obtained using a Quanta 650FEG (field emission gun) scanning electron microscope in the Laboratório Nacional de Luz Síncroton (LNLS/CNPEM). This new species was identified based in the key of cecidomiid species in GaGnÉ (2009). All types are deposited in the Museu de Zoologia of the Universidade de São Paulo (MZSP), São Paulo, Brazil.

\section{RESULTS AND DISCUSSION}

\section{Lopesia Rübsaamen, 1908}

\footnotetext{
Lopesia RüBSAAMEN 1908:29. Type species, Lopesia brasiliensis Rübsaamen (mon.). TAVARES, 1908 used “Lopesia n. g.” but noted that RüBSAAMEN had used the name earlier for the same genus and had priority.

Lopesla SHINJ, 1944:214, misspelling.
} 

(1994).

Diagnosis: see RÜBSAAmen (1908) and Gagné

\section{Lopesia eichhorniae Urso-Guimarães, sp. nov.}

(Figs 1-17)

Type material. BRAZIL, São Paulo: Luiz Antônio (Estação Ecológica do Jataí), in the Mogi-Guaçu River, Diogo Lake, Holotype: đ̊ (MZSP), col. 31.VII.2002; emerg. 03.VIII.2002, M. Peláez-Rodríguez col. Paratypes (MZSP): $\widehat{\delta}$ (col. and emerg. 14.I.2003); 2 ( (col. 31.VII.2002; emerg. 03.VIII.2002); 2 exuviae (col. 31.VII.2002; emerg. 03.VIII.2002); 1 pupa (col. 31.VII.2002); 9 larvae (col. 31.VII.2002), 1 larva (col. 14.i.2003).

Adult. Color: dark orange. Body length, 5 mm (male, $\mathrm{n}=2$ ) and $8 \mathrm{~mm}$ (female, $\mathrm{n}=2$ ). Head: Holoptic, compound eyes rounded, closely joined, without post-vertical peak (Fig. 1). Antenna: In male, length of antennae, $3.4 \mathrm{~mm}$, binodal flagellomeres, tri-circumfilar, basal and distal circumfila of each flagellomere with regular loops, medial circumfilum linear, flagellomeres necks bare, flagellomeres length varying $0.2-0.3 \mathrm{~mm}$ (Fig. 2). In female, length of antennae, $2.5 \mathrm{~mm}$ long; cylindrical with basal constriction and apressed circumfila, flagellomeres $1^{\text {st }}$ and $2^{\text {nd }}$ fused (Fig. 3 ), $12^{\text {th }}$ flagellomere with apical process in both sexes (Fig. 5, female), flagellomeres varying 0.1-0.3 mm (Figs 3, 4). Scape length $0.1 \mathrm{~mm}$ and pedicel length, $0.07 \mathrm{~mm}$, in both sexes. Palpus with three setose cylindrical segments (Fig. 6). Length of palpus: segment I: $0.04 \mathrm{~mm}$; II: $0.05 \mathrm{~mm}$; and III: $0.1(\mathrm{n}=3)$.
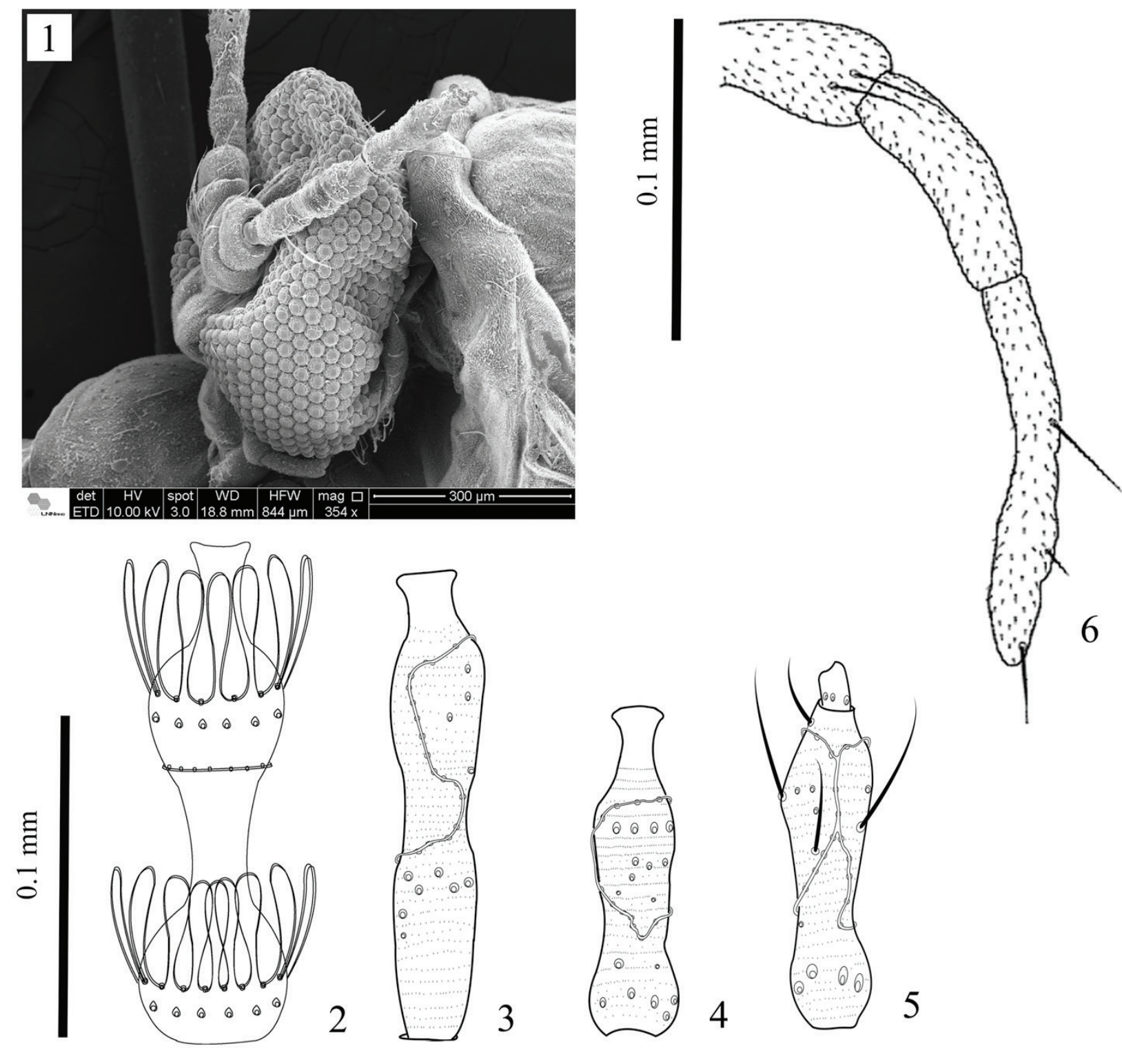

Figs 1-6. Lopesia eichhorniae sp. nov.: 1, female head, lateral; 2, holotype, male third binodal flagellomere; 3, female first and second flagellomere; 4 , female third flagellomere; 5 , female twelfth flagellomere; 6 , holotype, palpus. 
Thorax. Anepimeron with 24 setae $(n=4)$. Anepisternum bare. Wings: length, $5.2-6.5 \mathrm{~mm}(\mathrm{n}=4)$. Rs situated slightly after midlength of R1, strong as R1 and complete (Fig. 7). R5 joining $\mathrm{C}$ after wing apex. Cu forked and M3 present. Wing covered by setae and microsetae. Tarsal claws simple, bent before midlength, empodium rudimentar not reaching midlenght of tarsal claws.

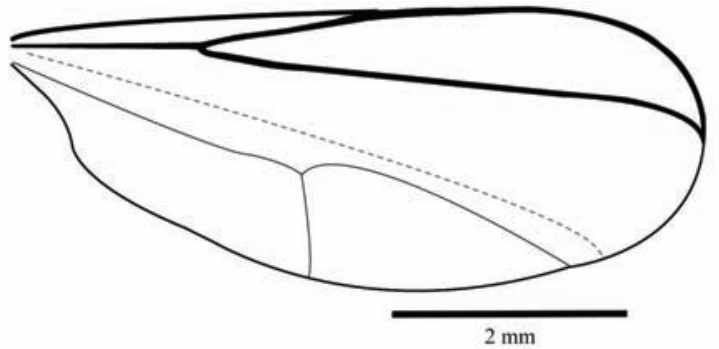

Fig. 7. Lopesia eichhorniae sp. nov. Holotype ふ̊̊, wing.

Abdomen (Figs 8, 9). Tergites 2-7 rectangular weakly sclerotized with a caudal row of strong setae, and one anterior pair of trichoid sensilla, tergite 8 not sclerotized. Sternites 2-8 rectangular, weakly sclerotized with a caudal row of strong setae. Trichoid sensilla not visible. Female terminalia: ovipositor not protrusible, cerci ovoid, separate, and setose bilobed hypoproct with microsetae (Fig. 8). Male terminalia (Holotype) (Fig. 9): gonocoxite splayed, longer than larger; mesobasal lobe rounded; gonostyle very sclerotized, enlarged in proximal portion tapering to apex, apex with entire tooth; hypoproct bilobed covered with setae and microsetae; hypoproct with $3 / 4$ of aedeagus length. Aedeagus constricted at tip, with longitudinal lines of microsetae. Cercus triangular and setose.

Pupa (Figs 10-14). Color: dark orange. Body length, $7.6 \mathrm{~mm}$ long $(\mathrm{n}=2)$. Head: integument smooth, short antennal horn, $0.01 \mathrm{~mm}$ long; cephalic setae absent; upper and lower frontal horns absent; lower and lateral facial papillae absent (Fig. 10); prothoracic spiracle triangular, strongly sclerotized (Fig. 11), $0.4 \mathrm{~mm}$ long; tergites with a sclerotized band with strong and complex spines varying 0.01- $0.09 \mathrm{~mm}$ long (Fig. 12, details of spines shape in Fig. 13); terminal segment sclerotized with bifurcated projection in both sexes, $0.3 \mathrm{~mm}$ long (Fig. 14).

Larva (Figs 15, 16). Color: cream. Body length, 5 $\mathrm{mm}(\mathrm{n}=3)$. Spatula $0.1 \mathrm{~mm}$, with two strong teeth laterally, serrate in the middle; shaft weakly sclerotized; thoracic segments with inner and outer groups with two setose and one asetose papillae each side of spatula (Fig. 15); terminal segment $0.5 \mathrm{~mm}$ long and $0.4 \mathrm{~mm}$ wide, with three pairs of corniform papillae; ventral anus (Fig. 16).

Gall (Fig. 17). Swollen rhizome of E. azurea (Pontederiaceae). Pupation occurs in gall. The oviposition and larval development cause the enlargement of the infected area of rhizome and a small change of natural color (Fig. 17). The oviposition in the rhizome occurs in the dry period (June to September).

Etymology. The name eichhorniae refers to the generic name of the host plant.

Comments. Lopesia eichhorniae sp. nov. differs from all previously described species by the following unique characters: larval spatula with two strong teeth laterally, serrate in the middle, shaft weakly sclerotized and cephalic setae absent; presence of a sclerotized band connecting the strong spines in median area of pupal tergites; pupal terminal segment with a pair of sclerotized projection; aedeagus with a constriction at tip and two longitudinal lines of microsetae, and triangular cercus in male. Furthermore, this is the first species reported in rhizome galls of E. azurea. The new species share characteristics with the previously described Lopesia species, as the strongly sclerotized thoracic spiracle of pupa with L. caulinaris Maia, 2003, L. erythroxyli Rodrigues \& Maia, 2010, L. maricaensis Rodrigues \& Maia, 2010, L. pernambucensis Maia, 2010, L. similis Maia, 2004, and

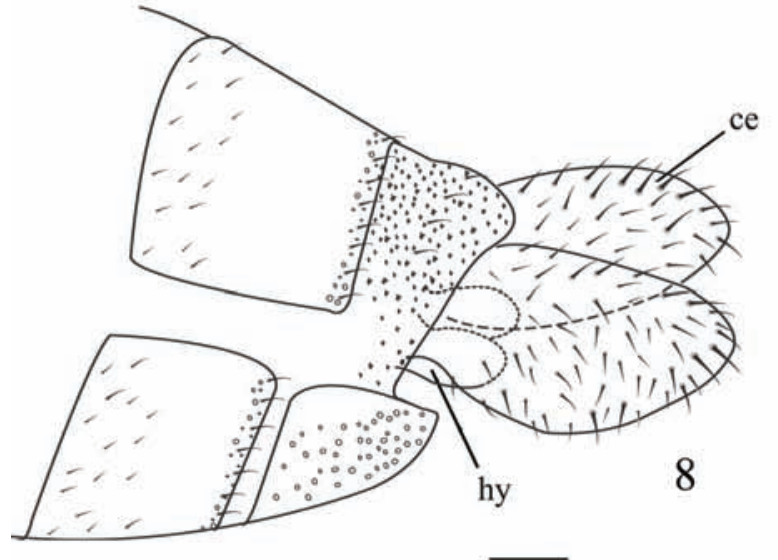

$0.1 \mathrm{~mm}$

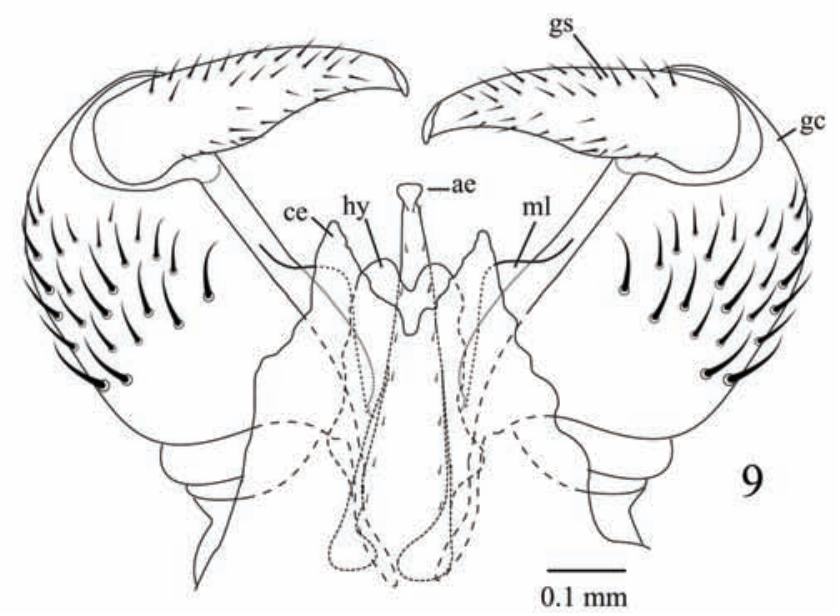

Figs 8, 9. Lopesia eichhorniae sp. nov.: 8, female terminalia, lateral; 9, holotype, male terminalia, dorsal (ae, aedeagus; ce, cercus; gc, gonocoxites; gs, gonostylus; hy, hypoproct; ml, mesobasal lobe). 

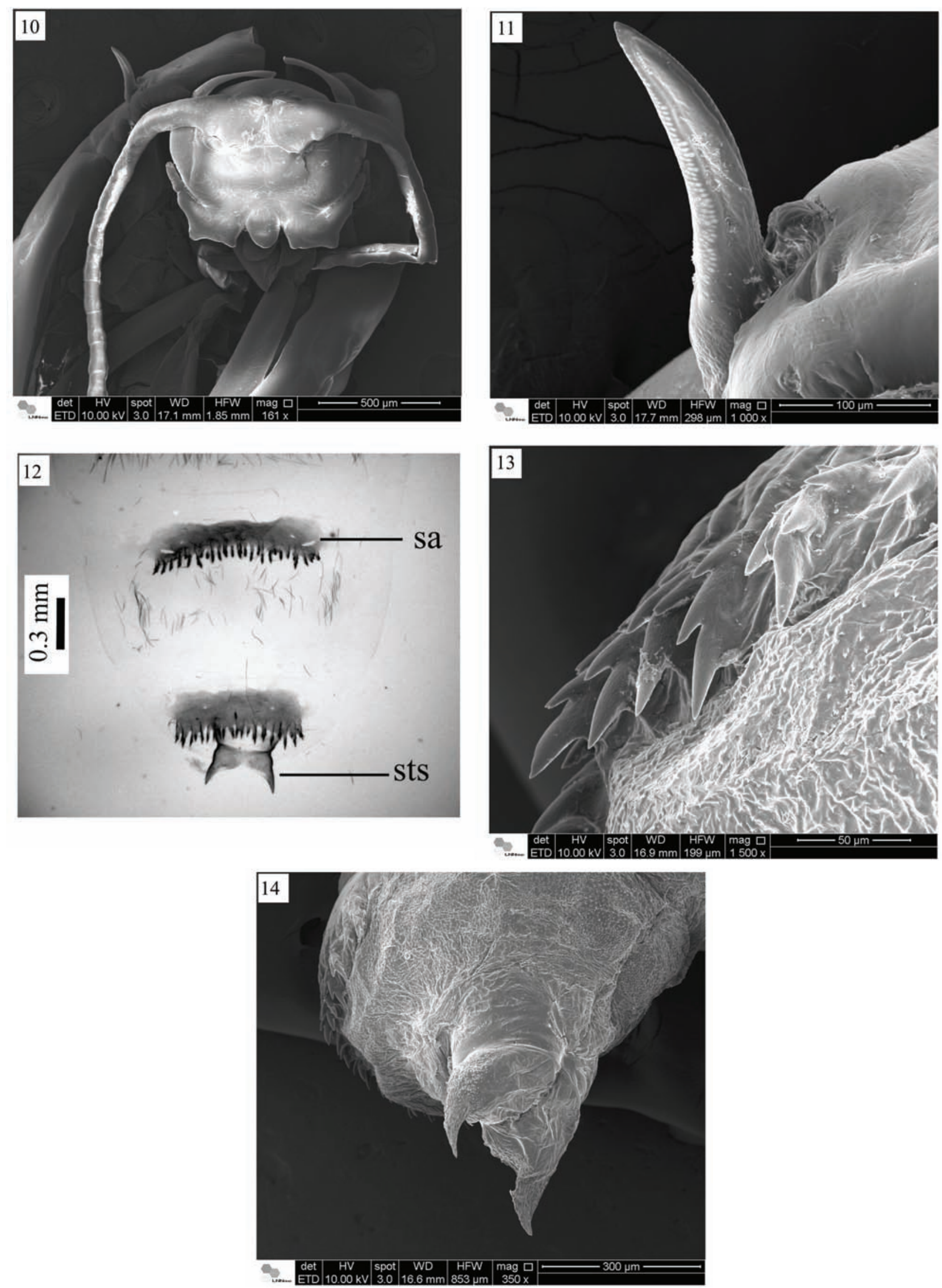

Figs 10-14. Pupa of Lopesia eichhorniae sp. nov.: 10, head, ventral; 11, protoracic spiracle, ventral; 12, terminal segment of abdomen, ventral; 13 , dorsal spines of tergites; 14 , terminal segment projection, lateral (sa, sclerotized area; sts, sclerotized terminal segment). 


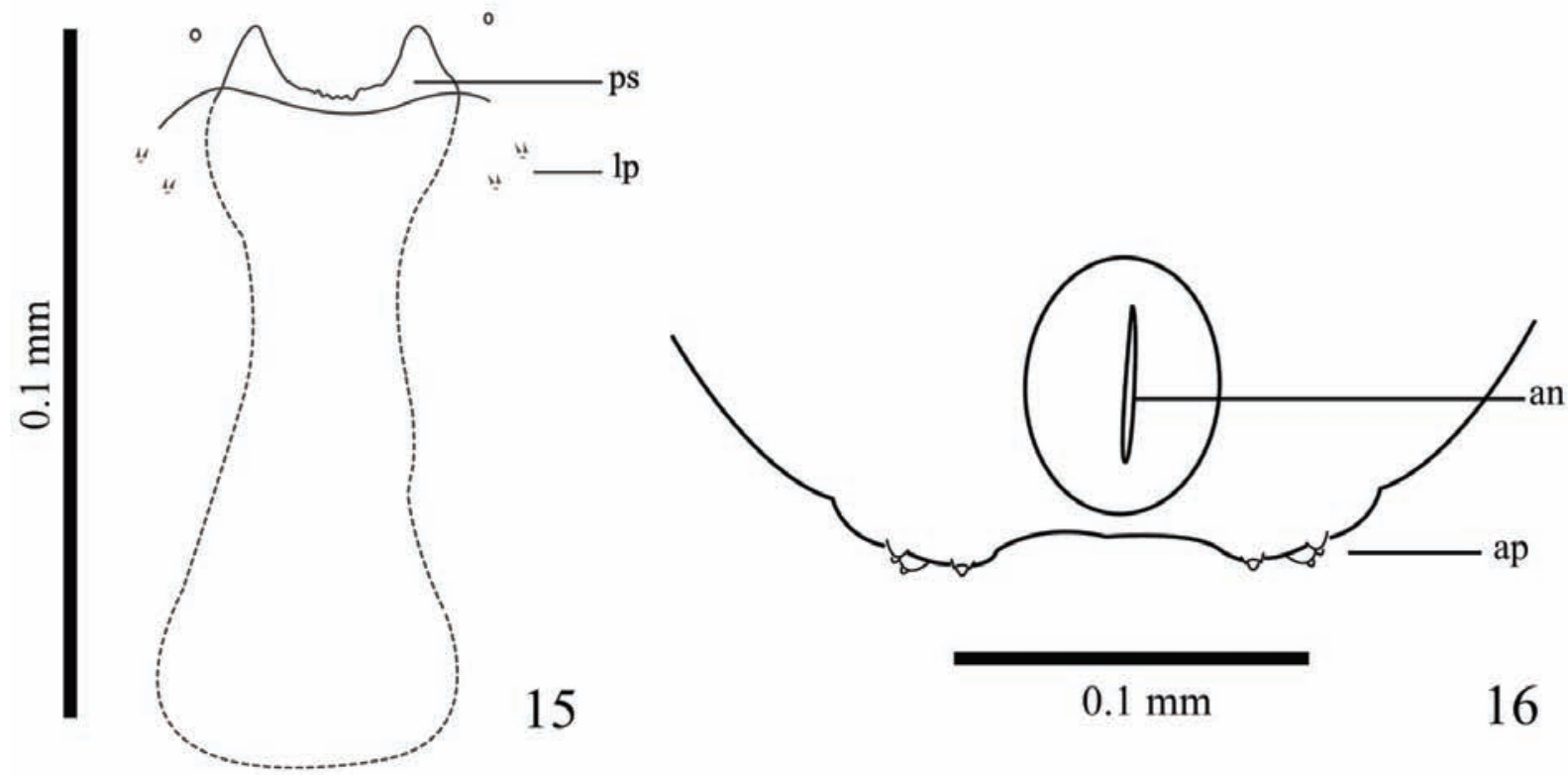

Figs 15, 16. Larva of Lopesia eichhorniae sp. nov.: 15, prothoracic spatula and lateral papillae, ventral; 16, terminal segment, ventral (an, anus; ap, anal papillae; lp, lateral papilla; ps, prothoracic spatula).

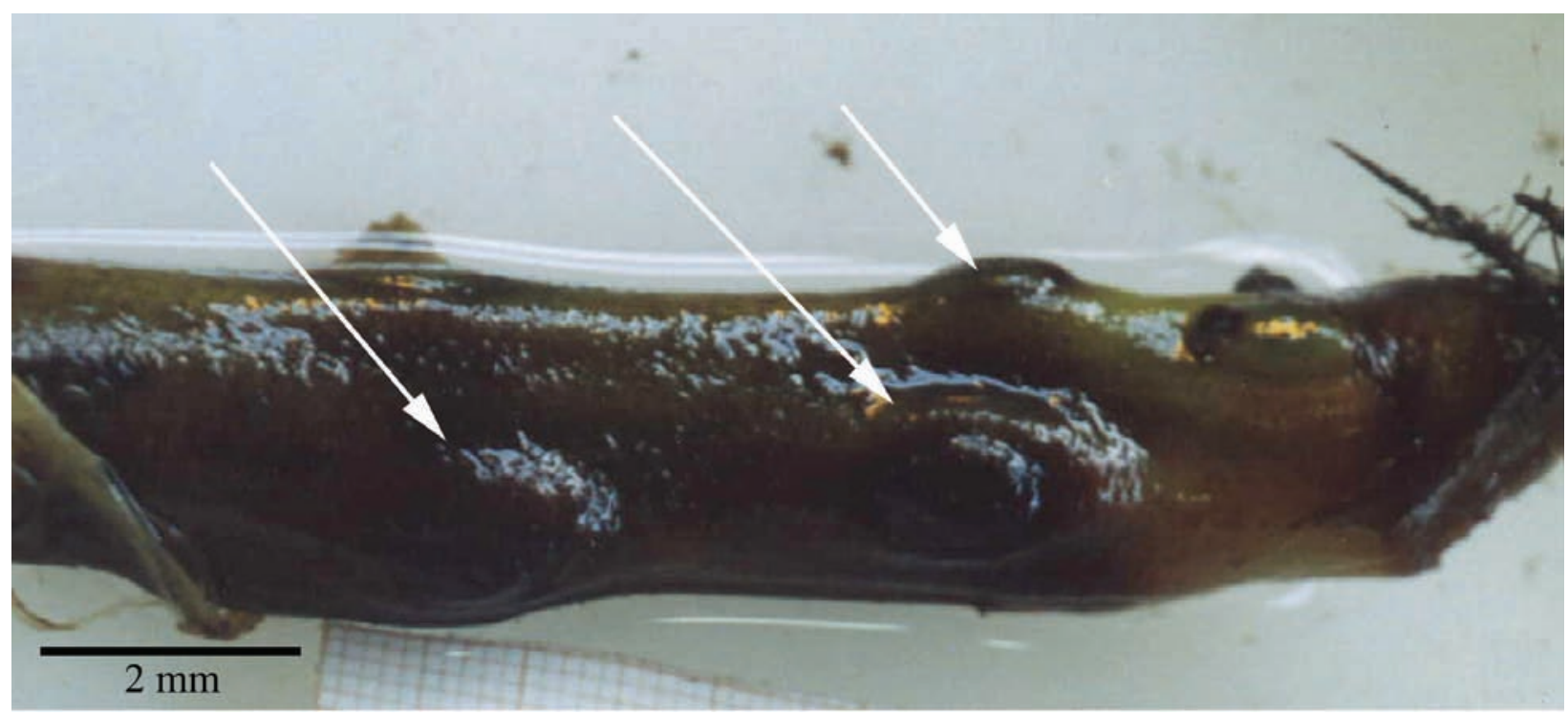

Fig. 17. General aspect of gall of Lopesia eichhorniae sp. nov. (arrows in galls).

L. simplex Maia, 2002; or the complex spines of pupal dorsal tergites are present also in L. caulinaris, L. bilobata Maia, 2004, L. brasiliensis Rübsaamen, 1908, L. conspicua Maia, 2003, L. elliptica Maia, 2003, L. grandis Maia, 2001. Despite the proximity pointed here by those features, additional phylogenetic studies are necessary to understand conclusively the relationships among those species.

Acknowledgements. The authors acknowledge help received from Dr. D. S. Amorim (FFCLRP/USP) and Laboratório de Microscopia Eletrônica (LME/LNLS/CNPEM). The paper was partially supported from FAPESP Proc. \# 99/01429-1.

\section{REFERENCES}

Amaral, M. C. E. 2014. Pontederiaceae in Lista de Espécies da Flora do Brasil. Jardim Botânico do Rio de Janeiro. Available at: $<$ http://reflora. jbrj.gov.br/jabot/floradobrasil/FB13741>. Acessed on: 14 July 2014.

Fernandes, S. P. C.; Maia, V. C. \& Rafael, J. A. 2010. Gall midges (Diptera, Cecidomyiidae) associated with Aldina heterophylla Spr. ex Benth. (Fabaceae) from Brazil. Biota Neotropica 10(1):161-166.

GaGnÉ, R. J. 1994. The Gall Midges of the Neotropical Region. Ithaca, Cornell University Press. 352p.

2009. Family Cecidomyiidae. In: Brown, B.V. et al. eds. Manual of Central American Diptera: Volume 1. Ottawa, NRC Research Press. 714p.

GaGNÉ, R. J. \& HibBARD, K. L. 1996. A new species of gall midge (Diptera: Cecidomyiidae) from subterranean stem galls of Licania michauxii (Chrysobalanaceae) in Florida. Florida Entomologist 79:428-434. 
Gagné, R. J. \& Jaschnof, M. 2014. A Catalog of the Cecidomyiidae (Diptera) of the World. 3ed. Digital version 2. Available at: <http:// www.ars.usda.gov/SP2UserFiles/Place/80420580/Gagne_2014_ World_Cecidomyiidae_Catalog_3rd_Edition.pdf $>$.

Gagné, R. J. \& Marohasy, J. 1993. The gall midges (Diptera: Cecidomyiidae) of Acacia spp. (Mimosaceae) in Kenya. Insecta Mundi 7(1-2):77-124.

Kolesik, P. \& PeAcock, D. E. 1999. A new species of gall midge (Diptera: Cecidomyiidae) damaging branch shoots of the dryland tea-tree, Melaleuca lanceolata (Myrtaceae). Transactions of the Royal Society of South Australia 123:115-119.

Madeira, J. A; Maia, V. C. \& Monteiro, R. F. 2003. Gall makers (Cecidomyiidae, Diptera) on Calophyllum brasiliense Camb. (Clusiaceae): descriptions and biology. Arquivos do Museu Nacional 61:31-48.

MaIA, V. C. 2001. New genera and species of gall midges (Diptera, Cecidomyiidae) from three restingas of Rio de Janeiro State, Brazil. Revista Brasileira de Zoologia 18 (Supl. 1):1-32.

. A new genus and six new species of gall midges (Diptera, Cecidomyiidae) from Serra de São José (Minas Gerais State, Brazil). Arquivos do Museu Nacional 62(1):69-82.

Maia, V. C.; Fernandes, G. W.; Magalhães, H. \& Santos, J. C. 2010. Two new species of Lopesia Rübsaamen (Diptera, Cecidomyiidae) associated with Mimosa hostilis (Mimosaceae) in Brazil. Revista Brasileira de Entomologia 54:578-583.

Maia, V. C.; Monteiro, R. F. \& Narahara, K. L. 2002. Two new species of gall midges (Diptera, Cecidomyiidae) associated with Protium icicariba (Burseraceae) in Brazil. Studia Dipterologica 9:171-178.
Narahara, K. L.: Maia, V. C. \& Monteiro, R. F. 2004. Two new species of gall midges (Diptera, Cecidomyiidae) associated with Protium heptaphyllum (Aubl.) Marchand in Brazil. Revista Brasileira de Entomologia 48:485-490.

Peláez-Rodríguez, M.; Trivinho-Strixino, S. \& Urso-Guimarães, M. V. 2003. Galls in rhizome of an aquatic macrophyte Eichhornia azurea (Swartz) Kunth (Pontederiaceae), in Jataí Ecological Station, Luiz Antônio, SP, Brazil. Brazilian Journal of Biology 63(4):723-726.

Ротт, V. J. \& Ротт, A. 2000. Plantas aquáticas do Pantanal. Brasília, Embrapa, Centro de Pesquisa Agropecuária do Pantanal. 404p.

Rodrigues, A. R. \& MAiA, V. C. 2010. Duas novas espécies de Lopesia Rübsaamen (Diptera, Cecidomyiidae) do Brasil, com chave para as espécies. Biota Neotropica 10:85-99.

RüBSAAMEN, E. H. 1908. Beiträge zur Kenntnis aussereuropäischer Zoocecidien. III. Beitrag: Gallen aus Brasilien und Peru. Marcellia 7:15-79.

SHINI, O. 1944. Galls and Gall Insects. Shunyodo, Tokyo. 602p.

TAVARES, J. S. 1908. Contributio prima ad cognitionem cecidologiae regionis zambeziae (Moçambique, Africa Orientalis). Brotéria, Série Zoológica 7:133-171.

Trivinho-Strixino, S.; Correia, L. C. S. \& Sonoda, K. 2000. Phytophilous chironomidae (Diptera) and other macroinvertebrates in the ox-bow Infernão Lake (Jataí Ecological Station, Luiz Antônio, SP, Brazil). Revista Brasileira de Biologia 60(3):527-535. 